\title{
Protective effect of betaine against skeleton muscle apoptosis in rats induced by chronic alcohol and statin consumption
}

\author{
Oglakci Ilhan $\mathrm{A}^{1}$, Ozkoc $\mathrm{M}^{2}$, Kusat $\mathrm{Ol} \mathrm{K}^{3}$, Karimkhani $\mathrm{H}^{4}$, Senturk $\mathrm{H}^{5}$, Burukoglu $\mathrm{D}^{6}$, Kanbak $\mathrm{G}^{2}$ \\ Cankiri Karatekin University, Eldivan Vocational School of Health Services, Cankiri, Turkey. \\ ayseguloi@karatekin.edu.tr
}

\begin{abstract}
AIM: The aim of the present study was to investigate the effect of apoptosis on rat skeletal muscle caused by chronic alcohol and statin consumption with modified liquid diet and to elucidate protective effects of betaine supplementation.

METHODS: TNF- $\alpha$ (tumor necrosis factor), NF-kB (Nuclear Factor kappa B), cytochrome $c$ and caspase-3 levels with or without betaine treatment in alcohol and/or statin-induced skeleton muscle apoptosis rats as well as in controls were measured in serum and tissue. Histologic examinations of the muscle tissues were also performed.

RESULTS: In our study, betaine treated treatment groups we found that calpain and caspase activities and cytokine c release were decreased caused by alcohol, statin and more importantly alcohol+statin group and TNF and NF-kB levels were also close to the levels of control group. Similarly, significant improvements have been observed in our morphological and histological examination results also supporting our biochemical data. CONCLUSION: We found that combined consumption of ethanol and statin is capable of triggering apoptotic cell death in rat muscles more than the consumption of only alcohol or only statin. Betaine was able to reduced this muscle cell death induced by alcohol and/or statin consumption (Tab. 4, Fig. 4, Ref. 43). Text in PDF www.elis.sk KEY WORDS: alcohol, statin, rat, muscle, apoptosis.
\end{abstract}

\begin{abstract}
Abbreviations: ADP: Adenosine diphosphate, AMC: 7-amino4-methyl coumarin, ATP: Adenosine triphosphate, CK: Keratin Kinase, JNK: Jun-N-terminal kinases, MLD: Modified Liquid Diet, NF: Nuclear Factor, NF-kB: Nuclear Factor kappa B, pNA: p-Nitroaniline, SAH: S-adenosylhomocysteine, SAM: S-adenosylmethionine, TNF- $\alpha$ : Tumor Necrosis Factor
\end{abstract}

\section{Introduction}

Primary disease of skeletal muscle is expressed in terms of myopathy. Myopathies may have genetic, infectious, autoimmune and toxic reason. Toxic myopathies can develop depending on

${ }^{1}$ Cankiri Karatekin University, Eldivan Vocational School of Health Ser-
vices, Çankiri, Turkey, ${ }^{2}$ Eskisehir Osmangazi University, Faculty of Medi-
cine, Department of Biochemistry, Eskisehir, Turkey, ${ }^{3}$ Turkish Health of
Ministry, Turkish Medicines and Medical Devices Agency, Ankara, Tur-
key, ${ }^{4}$ Istanbul Medipol University, Faculty of Medicine, Department of
Biochemistry, Istanbul, Turkey, ${ }^{5}$ Eskisehir Osmangazi University, Science
and Arts Faculty, Department of Biology, Eskisehir, Turkey, and ${ }^{6}$ Eskise-
hir Osmangazi University, Faculty of Medicine, Department of Anatomy,
Eskisehir Turkey Address for correspondence: A. Oglakci Ilhan, Cankiri Karatekin University, Eldivan Vocational School of Health Services, Cankiri, Turkey. Phone: +905532040394

Acknowledgements: This work was supported by TUBITAK 114S241 project. using drugs and alcohol. Alcohol can lead to acute and chronic myopathy depending on the period of use $(1,2)$. There are many medicines that are held responsible for the development of toxic myopathy. Statin derivative drugs that are used in the treatment of hypercholesterolaemia cause the development of myopathy (3). Although the mechanisms of statin induced myopathy is not fully understood, several theories have been proposed by researchers. These include alteration of the level of ubiquinone or alteration of the sarcolemic cholesterol content or proteolysis and induction of apoptosis. The most important group of membrane receptors involved in apoptosis is actively induced by several structurally related receptors, called death receptors. The best known are TNFalpha and Fas receptors (4). TNF- $\alpha$ is caused by apoptosis with 3 important signaling pathways. The first pathway triggers apoptosis by triggering caspases through the FADD-associated death zone (FADD). The second pathway activates Jun-N-terminal kinases (JNK) and transcription factor AP-1, again leading to apoptosis. In the third pathway, it activates NF- $\kappa \mathrm{B}$, the main mediator in the control of TNF- $\alpha$ transcription. TNF- $\alpha$ is important in the activation and translocation of NF- $\mathrm{\kappa B}$ in the skeleton (5). NF-kB increases the expression of several members of the $\mathrm{Bcl} 2$ family that inhibits apoptosis by inhibiting cytochrome c release and mitochondrial permeability (6). The $\mathrm{Bcl}-2$ (antiapoptotic protein) family is the most important group in the control of the apoptotic cascade and has a large number of squamous cells. Bcl-2 protect mitochondria membrane permeability. It inhibits apoptosis by in- 
hibiting proapoptotic proteins (Bax and $\mathrm{Bad}$ ) (7). Bax protein is a proapoptotic protein and has an important role in the induction of apoptosis (8). In healthy cells Bax is found in cytosol. Apoptotic stimulation leads to cytosolic bax to mitochondria and, as a result of various changes, hydrophobic C-terminus of Bax is released and causes cytochrome c release (7). Released cytochrome c plays an important role for caspase-3 activation in apoptotic cell death. Activation of the cofactor nucleotide triphosphate (d-ATP and ATP) activates cytochrome $\mathrm{c}$ and apaf-1 to activate procaspase-9. Activated caspase- 9 also activates caspase- 3 and triggers the other caspase cascade (9). The release of Bax is stimulated by the calpain, resulting in the release of cytochrome c (7). Calpains are calcium-dependent thiol-proteases (10). Calpains are proteases involved in cell skeleton and signal transduction. They are also involved in other physiological and pathophysiological processes such as cell cycle regulation, apoptosis, inflammation, ischemia, muscular dystrophy, cataractogenesis, Alzheimer's and Parkinson's diseases (11). Activated calpains promote apoptosis by causing caspase 9 and 3 activation (7).

Skeletal myopathy is observed in $30 \%$ to $50 \%$ of high-dose chronic alcohol consumers and it has been related to a direct dosedependent toxic effect of ethanol. However, its pathogenesis has not been clearly established (12). Apoptosis may be responsible for the progressive intrinsic contractile dysfunction of skeletal myocytes and progressive myocyte loss in alcoholic myopathy (13). Ethanol may activate apoptosis through diverse mechanisms, with the increase in TNF, activation of nuclear-factor-(NF), activation of mitochondrial caspases and disruption of intracellular $\left(\mathrm{Ca}^{2+}\right)$ transients being the most frequently implicated (12). The change in intracellular calcium level triggers pathways that cause apoptosis. It is thought that calcium plays a role in dephosphorylation of Bad which affects cytochrome c release. Similarly, $\left(\mathrm{Ca}^{2+}\right)$-dependent cysteine protease calpain, providing Bax cleavage and it causes Bax to perform its proapoptotic activity. Furthermore, $\left(\mathrm{Ca}^{2+}\right)$ has been implicated in the release of cytochrome $\mathrm{c}$ by affecting the mitochondrial membrane transition pores during apoptosis (14). Cytochrome c can initiate the activation cascade of caspases once it is released into the cytosol and lead to apoptosis (15).

Natural products have been the starting point for the discovery of many modern medicines. Betaine was first discovered in the sugar beet (Beta vulgaris) juice in the 19th century and is known to be present in some other organisms (16). Betaine, a molecular chaperone task, is an inhibitor of oxidative stress and mitochondrial damage (17). It is the methyl source of the transmethylation reactions used in many biochemical pathways, thus providing single carbon units to be used in the formation of methionine and cholines necessary for optimal nutrition (16). The conversion of homocysteine to methionine is necessary for the maintenance of the level of methionine, the detoxification of homocysteine and the production of S-adenosylmethionine (SAM). Ethanol consumption increases the rate of S-adenosylhomocysteine (SAH) in liver cells (19). Betaine reduces the rate of increasing SAH (17). In recent years, an increase in the number of intracellular SAHs has been reported with increasing apoptosis in many different cell types $(18,19)$.
In our study, supported by Tübitak 1002 support program, the role of statin use on skeletal muscle apoptotic cell death and the protective role of betaine in chronic alcohol consumption were investigated biochemically and histologically. Orally, betaine treatment has been shown to reduce liver necrosis, liver fat accumulation, apoptosis induced in various forms. A similar result was aimed at seeing when chronic alcohol use and statin use coexist. In this context; as a result of chronic alcohol use TNF- $\alpha$, NF-kB, cytochrome $\mathrm{c}$ and caspase-3 levels as markers of skeletal apoptosis and statin consumption in rat muscle tissues were determined from cysteine proteases known to be involved in triggering apoptosis. $\mathrm{CK}$ enzyme levels, which are muscle injury indicators in serum of rats, were measured. Bcl-2 and Bax levels were determined by immunohistochemical analysis, TUNEL method and light microscopy. The results obtained here provide us with the first information in the literature about whether there is a protective role for betaine on the use of statin along with chronic alcohol consumption and will shed light on the development of different treatment strategies for the use of stain during chronic alcohol use.

\section{Materials and methods}

\section{Materials}

56 adult male Sprague-Dawley rats weighting 160-195 g were obtained from TICAM (Medical and Surgical Experimental Research Center, Eskisehir-TURKEY) and housed in polycarbonate cages in a room with controlled temperature (22 $\pm 2 \mathrm{DC})$, humidity $(50 \pm 5 \%)$, and a 12 hour cycle of light and dark (07:00 AM-07:00 PM light). The rats were placed in separate cages and acclimated to laboratory conditions for one week before starting the experiments. The rats were randomized into 7 groups, each consisting of 8 animals.

Control group $(\mathrm{n}=8)$ : Received isocaloric modified liquid diet (MLD)

Alcohol group $(n=8)$ : Received MLD solution with ethanol

Statin group $(\mathrm{n}=8)$ : Received isocaloric MLD and $10 \mathrm{mg} / \mathrm{kg}$ atorvastatin

Alcohol+statin group $(n=8)$ : Received MLD solution with ethanol and $10 \mathrm{mg} / \mathrm{kg}$ atorvastatin

Alcohol+betaine group $(n=8)$ : Received MLD solution with ethanol and betaine $(1 \% \mathrm{w} / \mathrm{v})$.

Statin+betaine group $(\mathrm{n}=8)$ : Received isocaloric MLD, $10 \mathrm{mg} / \mathrm{kg}$ atorvastatin and betaine $(1 \% \mathrm{w} / \mathrm{v})$

Alcohol+statin+betaine group $(\mathrm{n}=8)$ : Received MLD solution with ethanol, $10 \mathrm{mg} / \mathrm{kg}$ atorvastatin and betaine $(\% 1 \mathrm{w} / \mathrm{v})$

The MLD comprised $925 \mathrm{ml}$ low fat cows' milk (Sütaş, Eskisehir, Turkey), from 25 to $75 \mathrm{ml}$ alcohol (96.5\% v/v ethanol; Merck Millipore, Darmstadt, Germany) and $17 \mathrm{~g}$ sucrose (Merck Millipore). The caloric content of the diet was $1,007 \mathrm{kcal} / 1$. The weight of the rats was recorded every day and the daily alcohol intake was also measured. The MLD was prepared daily and given to the animals while fresh. Extra chow or water were not available during the experimental period. At the beginning of the study, the rats were given MLD without alcohol for 2 days. Then, a liquid diet with $2.4 \%$ alcohol was administered for 3 days. The alco- 
Tab. 1. Biochemical results of groups.

\begin{tabular}{|c|c|c|c|c|c|c|}
\hline Group & $\begin{array}{l}\text { CK-MB } \\
\text { (ng/ml) }\end{array}$ & $\begin{array}{c}\text { Cytochrome C } \\
(\mathrm{C} / \mathrm{M})\end{array}$ & $\begin{array}{c}\mathrm{TNF} \alpha \\
\text { (pg/mg protein) }\end{array}$ & $\begin{array}{c}\text { NF kB } \\
\text { (ng/mg protein) }\end{array}$ & $\begin{array}{c}\text { Caspase } 3 \\
\text { ( } \mu \text { mol pNA/minute/ } \\
\text { /mg protein) }\end{array}$ & $\begin{array}{c}\text { Calpain } \\
\text { (pmol/minute/ } \\
\text { /mg protein) }\end{array}$ \\
\hline Control & $24.63 \pm 4.32$ & $1.40 \pm 0.46$ & $10.50 \pm 2.66$ & $11.52 \pm 2.86$ & $0.25 \pm 0.14$ & $1.54 \pm 0.32$ \\
\hline Alcohol & $32.97 \pm 6.75^{\mathrm{a}}$ & $3.05 \pm 0.78^{\mathrm{a}}$ & $16.71 \pm 1.65^{\mathrm{a}}$ & $17.78 \pm 2.06^{\mathrm{a}}$ & $0.35 \pm 0.15$ & $4.93 \pm 1.79^{\mathrm{a}}$ \\
\hline Statin & $36.92 \pm 7.72^{\mathrm{a}}$ & $1.78 \pm 0.57$ & $16.06 \pm 3.94^{\mathrm{a}}$ & $14.66 \pm 3.57$ & $0.31 \pm 0.03$ & $3.15 \pm 0.75^{\mathrm{a}, \mathrm{b}}$ \\
\hline Alcohol+Betaine & $22.43 \pm 2.38^{\mathrm{b}, \mathrm{c}, \mathrm{d}}$ & $1.48 \pm 0.41^{\mathrm{b}}$ & $11.17 \pm 2.16^{\mathrm{b}, \mathrm{c}, \mathrm{d}}$ & $12.25 \pm 2.29^{\mathrm{b}}$ & $0.30 \pm 0.21^{\mathrm{d}}$ & $3.23 \pm 1.26^{\mathrm{a}, \mathrm{b}}$ \\
\hline Alcohol+Statin & $39.06 \pm 5.12^{\mathrm{a}}$ & $3.20 \pm 1.98^{\mathrm{a}, \mathrm{c}}$ & $16.39 \pm 1.93^{\mathrm{a}}$ & $16.54 \pm 3.06^{\mathrm{a}, \mathrm{e}}$ & $0.90 \pm 0.39^{\mathrm{a}, \mathrm{b}, \mathrm{c}}$ & $3.96 \pm 0.97^{\mathrm{a}}$ \\
\hline Alcohol+Statin+Betaine & $26.51 \pm 6.38^{\mathrm{c}, \mathrm{d}}$ & $1.58 \pm 0.63^{\mathrm{b}, \mathrm{d}}$ & $11.97 \pm 1.69^{\mathrm{b}, \mathrm{c}, \mathrm{d}}$ & $13.08 \pm 1.77^{\mathrm{b}}$ & $0.39 \pm 0.15^{\mathrm{d}}$ & $3.14 \pm 0.81^{\mathrm{a}, \mathrm{b}}$ \\
\hline
\end{tabular}

Distribution of creatine kinase, cytochrome c, TNF- $\alpha$, NF Kb, caspase- 3 and calpain levels in rat groups. The results are expressed as mean \pm standard deviation. a: Significant difference from control group $(p<0.05)$, b: Significant difference from alcohol group $(p<0.05)$, c: Significant difference from statin group ( $<<0.05)$, d: Significant difference from alcohol+statin group $(\mathrm{p}<0.05)$, d: Significant difference from alcohol+betaine group $(\mathrm{p}<0.05)$

Tab. 2. Histological results of groups.

\begin{tabular}{|c|c|c|c|c|c|}
\hline & \multicolumn{5}{|c|}{ Groups (median 25-75\%) } \\
\hline & Necrosis & Myofibrillar degeneration & Nuclear proliferation & Nuclear hypertrophy & Edema \\
\hline Control & $\begin{array}{c}0.00 \\
(0.00-0.00)\end{array}$ & $\begin{array}{c}0.20 \\
(0.00-1.00)\end{array}$ & $\begin{array}{c}0.00 \\
(0.00-0.00)\end{array}$ & $\begin{array}{c}0.10 \\
(0.00-1.00)\end{array}$ & $\begin{array}{c}0.00 \\
(0.00-0.00)\end{array}$ \\
\hline Alcohol & $\begin{array}{c}1.25 \\
(1.00-2.00)^{\mathrm{a}}\end{array}$ & $\begin{array}{c}1.30 \\
(1.00-2.00)^{\mathrm{a}}\end{array}$ & $\begin{array}{c}1.40 \\
(1.00-2.00)^{\mathrm{a}}\end{array}$ & $\begin{array}{c}1.30 \\
(1.00-2.00)^{\mathrm{a}}\end{array}$ & $\begin{array}{c}1.30 \\
(1.00-2.00)^{\mathrm{a}}\end{array}$ \\
\hline Statin & $\begin{array}{c}1.25 \\
(1.00-2.00)^{\mathrm{a}}\end{array}$ & $\begin{array}{c}1.40 \\
(1.00-2.00)^{\mathrm{a}}\end{array}$ & $\begin{array}{c}1.30 \\
(1.00-2.00)^{\mathrm{a}}\end{array}$ & $\begin{array}{c}1.20 \\
(1.00-2.00)^{\mathrm{a}}\end{array}$ & $\begin{array}{c}1.40 \\
(1.00-2.00)^{\mathrm{a}}\end{array}$ \\
\hline Alcohol+Statin & $\begin{array}{c}2.80 \\
(2.00-3.00)^{\mathrm{a}, \mathrm{b}}\end{array}$ & $\begin{array}{c}2.70 \\
(2.00-3.00)^{\mathrm{a}, \mathrm{b}}\end{array}$ & $\begin{array}{c}2.90 \\
(2.00-3.00)^{\mathrm{a}, \mathrm{b}}\end{array}$ & $\begin{array}{c}2.70 \\
(2.00-3.00)^{\mathrm{a}, \mathrm{b}}\end{array}$ & $\begin{array}{c}2.80 \\
(2.00-3.00)^{\mathrm{a}, \mathrm{b}}\end{array}$ \\
\hline Alcohol+Betaine & $\begin{array}{c}0.75 \\
(0.00-1.00)^{\mathrm{a}, \mathrm{c}} \\
\end{array}$ & $\begin{array}{c}0.60 \\
(0.00-1.00)^{\mathrm{b}}\end{array}$ & $\begin{array}{c}0.80 \\
(0.00-1.00)^{\mathrm{a}, \mathrm{b}, \mathrm{c}}\end{array}$ & $\begin{array}{c}1.00 \\
(0.00-2.00)^{\mathrm{a}, \mathrm{c}} \\
\end{array}$ & $\begin{array}{c}0.80 \\
(0.00-2.00)^{\mathrm{a}, \mathrm{c}} \\
\end{array}$ \\
\hline Statin+Betaine & $\begin{array}{c}0.50 \\
(0.00-1.00)^{\mathrm{a}, \mathrm{b}} \\
\end{array}$ & $\begin{array}{c}0.80 \\
(0.00-1.00) \\
\end{array}$ & $\begin{array}{c}0.80 \\
(0.00-1.00)^{\mathrm{a}} \\
\end{array}$ & $\begin{array}{c}0.80 \\
(0.00-1.00)^{\mathrm{a}}\end{array}$ & $\begin{array}{c}0.80 \\
(0.00-2.00)^{\mathrm{a}}\end{array}$ \\
\hline Alcohol+Statin + Betaine & $\begin{array}{c}0.25 \\
(0.00-1.00)^{\mathrm{b}, \mathrm{c}, \mathrm{d}}\end{array}$ & $\begin{array}{c}0.20 \\
(80.00-1.00)^{\mathrm{b}, \mathrm{c}, \mathrm{d}}\end{array}$ & $\begin{array}{c}0.10 \\
(0.00-1.00)^{\mathrm{b}, \mathrm{c}, \mathrm{d}}\end{array}$ & $\begin{array}{c}0.30 \\
(0.00-1.00)^{\mathrm{b}, \mathrm{c}, \mathrm{d}}\end{array}$ & $\begin{array}{c}0.20 \\
(0.00-1.00)^{\mathrm{b}, \mathrm{c}, \mathrm{c}}\end{array}$ \\
\hline
\end{tabular}

Light microscopic evaluations: (0) no injury. (1) mild. (2) moderate and (3) severe. a: Statistical difference compared with control group $\mathrm{p}<0.05$. b: Statistical difference compared with alcohol group $\mathrm{p}<0.05$. c: Statistical difference compared with alcohol+statin groups $\mathrm{p}<0.05$. d: Statistical difference compared with alcohol + betaine groups $\mathrm{p}<0.05$

hol concentration was increased to $4.8 \%$ during the following 4 days and finally reached $7.2 \%$ over the next 21 days. Isocaloric modified liquid diet containing sucrose as a caloric substitute for alcohol (96 g sucrose and $75 \mathrm{ml}$ cows' milk replaced $60.75 \mathrm{~g}$ or $75 \mathrm{ml}$ ethanol) $(20,21)$.

$10 \mathrm{mg} / \mathrm{kg}$ atorvastatin was dissolved in $0.9 \% \mathrm{NaCl}$ by a magnetic stirrer and given oral gavage for 30 days at the same time.

The rats were anesthetized (Ketamine / Xylazine 3: 1, $1.32 \mathrm{mg}$ $/ \mathrm{kg}$ intraperitoneal) and blood was taken from their hearts. Skeletal muscle was surgically removed. Tissues used for biochemical studies were frozen and kept at $-80{ }^{\circ} \mathrm{C}$ until they were tested. For histological studies, the tissues were fixed in neutral form for 24-48 hours. Routine histologic follow-up of tissues was done after fixation. All experiments were carried out in accordance with institutional guidelines for animal welfare (Eskisehir Osmangazi University Animal Care and Use Committee, Eskisehir, Turkey) and were approved by the Ethics Committee of the Medical and Surgical Experimental Research Center of Osmangazi University

\section{Methods}

Measurement of CK Activity: Serum was measured using the CK Elisa kit (MAK116, Sigma-Aldrich).
Measurement of TNF- $\alpha$ Levels: Tissue TNF-a levels were measured using a quantitative ELISA test kit (RAB0479, SigmaAldrich).

Measurement of NF kB Levels: Tissue NF kB levels were measured using a quantitative ELISA test kit (CSB-E13148r, Cusabio).

Measurement of Caspase-3 Activities: Tissue samples were homogenized (1/10 w/v) in lysis buffer (250 mM HEPES, pH 7.4, $1 \%$ CHAPS, $50 \mathrm{mM}$ DTT, $10 \mathrm{mM}$ EDTA) and then centrifuged for $20 \mathrm{~min}$ at $3,000 \mathrm{rpm}$ and $4{ }^{\circ} \mathrm{C}$. Supernatants were collected and centrifuged twice at 14,000 rpm for $15 \mathrm{~min}$ (22). Commercial assay kit (Sigma CASP-3-C) was used to measure caspase-3 activities in supernatant fractions. Results were expressed in $\mu \mathrm{mol}$ $\mathrm{pNA} /$ minute.

Measurement of Cytochrome-c Release: Cytochrome c levels were measured in both cytosolic and mitochondrial fractions using a commercial assay kit (R\&D Systems MCTC0) and cytosolic fraction/mitochondrial fraction ratios were used as indicators of mitochondrial damage $(23,24)$.

Calpain Activity Assay: The difference between measurement rates in calcium free and calcium containing assay buffer was used to determine calpain activity. Calpain activity was determined as the difference between the calcium-dependent fluorescence and the 

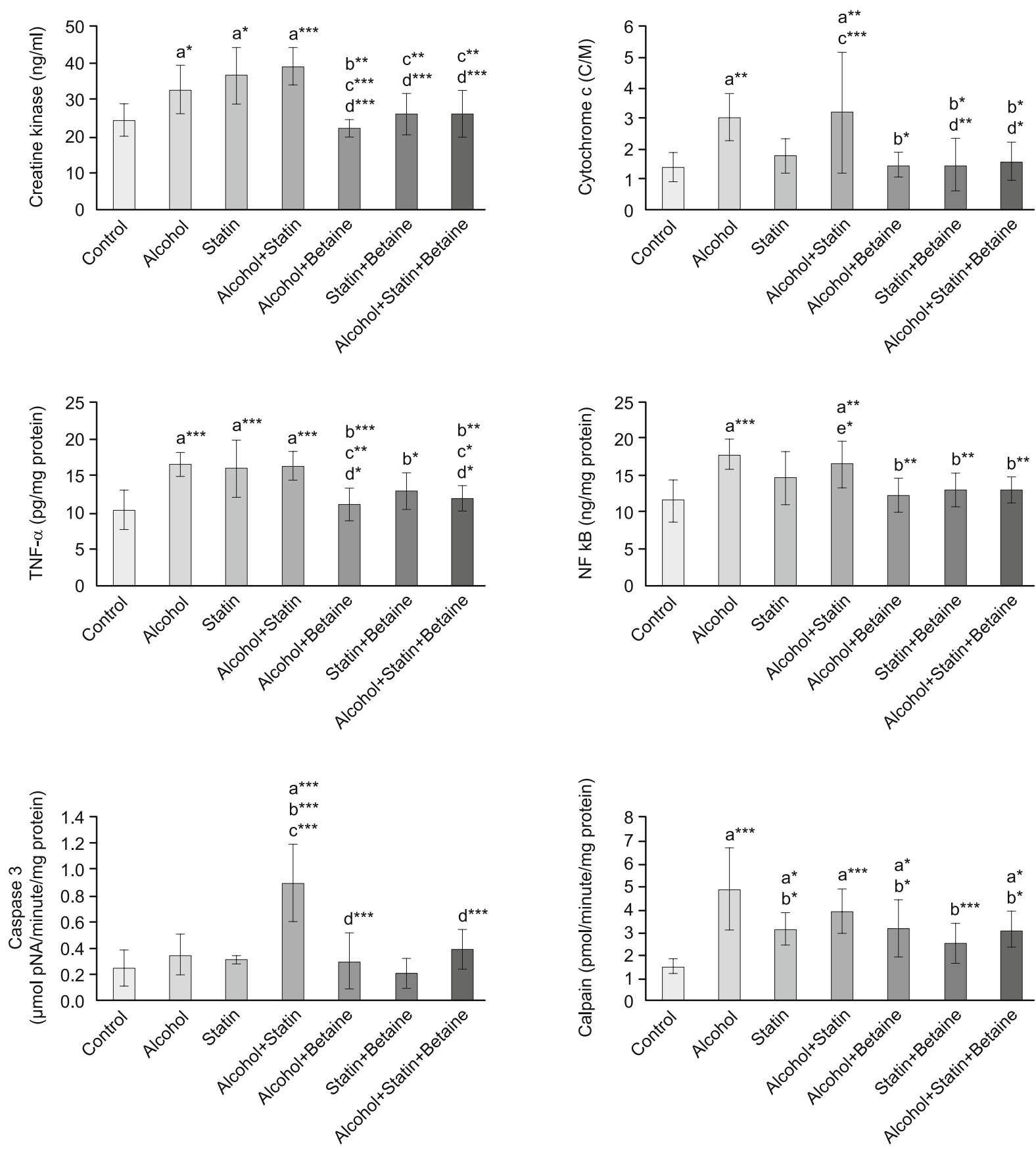

Fig. 1. Distribution of creatine kinase, cytochrome c, TNF- $\alpha, \mathrm{NF} \mathrm{Kb}$, caspase-3 and calpain levels in rat groups. The results are expressed as mean \pm standard deviation in eight rat of each groups. $a^{*}$ : Compared with control group $p<0.047, a^{* *}$ : Compared with control group $p<0.010$, $a^{* * *}$ : Compared with control group $p<0.001, b^{*}$ : Compared with alcohol group $p<0.047, b^{* *}$ : Compared with alcohol group $p<0.010, b^{* * *}$ : Compared with alcohol group $p<0.001, c^{*}$ : Compared with statin group $p<0.047, \quad \mathbf{c}^{* *}$ : Compared with statin group p $<0.010, \quad \mathbf{c}^{* * *}:$ Compared with statin group $p<0.001, d^{*}$ : Compared with alcohol+statin group $p<0.047, d^{* *}$ : Compared with alcohol + statin group $p<0.010, d^{* * *}$ : Compared with alcohol+statin group $\mathrm{p}<0.001, \mathrm{e}^{*}$ : Compared with alcohol+betain group $\mathrm{p}<0.047$

noncalcium-dependent fluorescence. A 7-amino-4-methyl coumarin (AMC) standard curve was constructed. Calpain activity was expressed as pm of AMC released per minute of incubation time per minute of total protein (25).

\section{Histological analysis}

At the end of the experimental period all the groups were sacrificed with anesthesia and muscle specimens of rats were fixed in $10 \%$ formalin fixative for 48 hours in order to be able to perform his- 

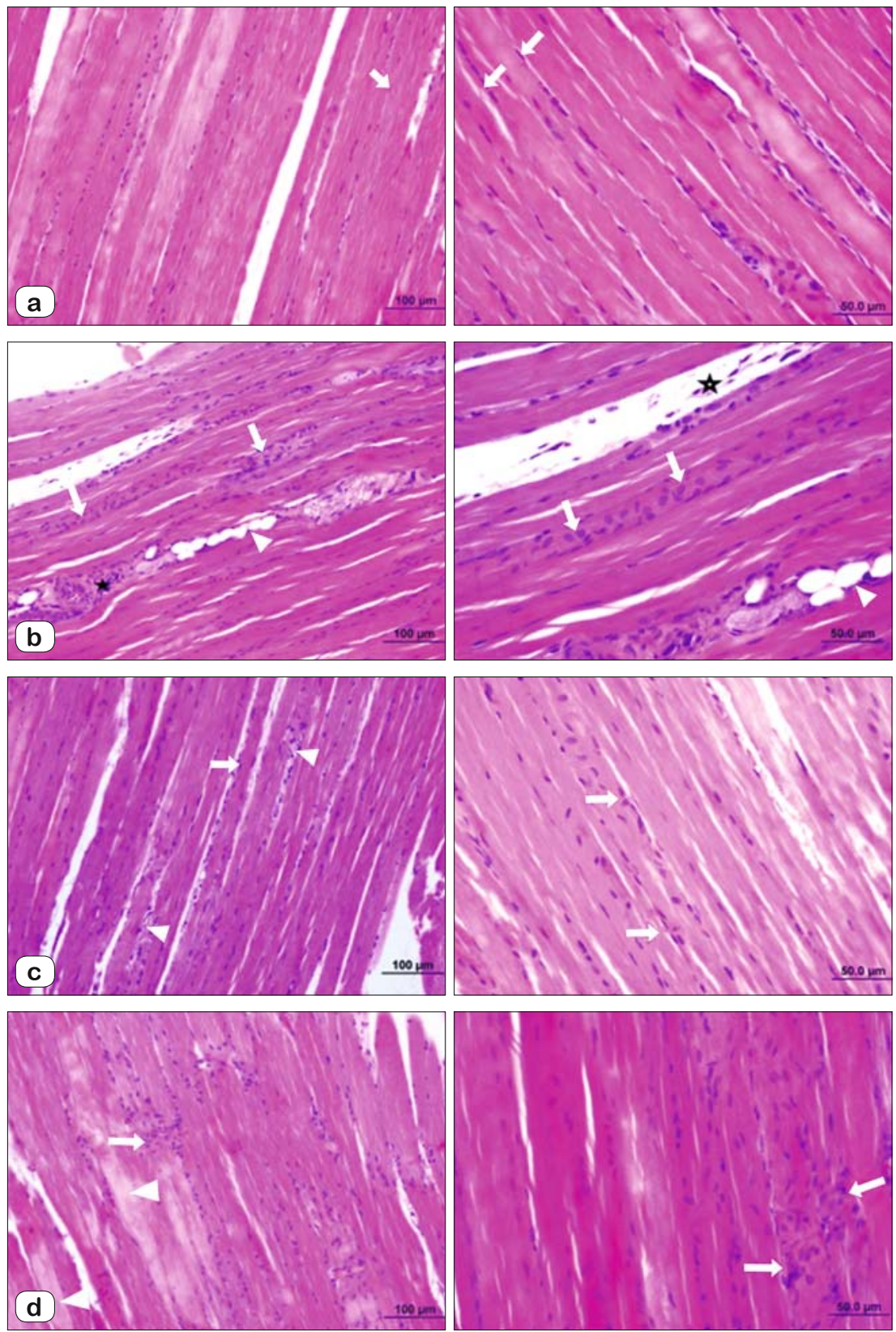

Fig. 2. Light microscope results in rat groups (a-g). a) Control group, the overall appearance. Located peripheral nuclei $\rightarrow$ ), (HE, scale bar: $100 \mu \mathrm{m}$, X20, scale bar: $50.0 \mu \mathrm{m}$, X40). b) Alcohol group: (*) partial edema, $(\triangleright)$ vacuolization, $(\rightarrow)$ nuclear hypertrophy (HE, scale bar: $100 \mu \mathrm{m}$, X20, scale bar: $50.0 \mu \mathrm{m}, \mathrm{X} 40)$. c) Statin group: $(\triangleright)$ partial edema, $(\rightarrow)$ nuclear hypertrophy (HE, scale bar: $100 \mu \mathrm{m}, \mathrm{X20}$, scale bar: $50.0 \mu \mathrm{m}, \mathrm{X40}$ ). d) Alcohol+statin group: $>$ ) necrotic myofibrils, $(\rightarrow$ ) nuclear proliferation (HE, scale bar: $100 \mu \mathrm{m}$, X20, scale bar: $50.0 \mu \mathrm{m}, \mathrm{X40}$ ).

tological examinations at light microscopic level. The samples were subjected to routine procedures, were processed into paraffin-embedded blocks. $5 \mu \mathrm{m}$-sections were obtained from each paraffin-embedded block, and these sections were stained with Hematoxylin Eosin and examined under Olympus BH-2 microscope and photographed. In addition, sections were taken for TUNEL staining to determine apoptotic cells from all muscle tissue specimens. The paraffins of the preparations were melted at 60 degrees for 1 hour. Then TUNEL staining technique was applied to muscle tissue specimens. Immunohistochemically, sections were taken from the same muscle tissue samples and Bcl-2 and Bax levels were measured.

\section{Statistical analysis}

SPSS software, version 15.0 for Windows (SPSS, Inc., Chicago, IL, USA) was used for the statistical analysis of biochemical data. In order to assess differences between groups, one-way analysis of variance (ANOVA) and Tukey's multiple comparison test were used. Results are presented as mean \pm standard deviation and $\mathrm{p}<0.05$ was considered to indicate a statistically significant result.

\section{Results}

\section{Biochemistry results}

CK levels: Serum CK levels in the alcohol ( $\mathrm{p}<0.047)$, statin $(\mathrm{p}<0.010)$ and alcohol+statin $(\mathrm{p}<0.001)$ groups were significantly increased compared with the control group. The CK levels in the alcohol+betaine group exhibited a significant reduction compared with the alcohol, statin and alcohol+statin group (respectively $\mathrm{p}<0.010, \mathrm{p}<0.001, \mathrm{p}<0.001)$. The CK levels in the statin+betaine and alcohol+statin+betaine group were decreased compared with the statin group $(\mathrm{p}<$ 0.010). The CK levels of the statin+betaine and alcohol+statin+betaine were found to be significantly lower compared with alcohol+statin group $(\mathrm{p}<0.001)$ (Tab. 1)

Cytochrome-c release: Cytochromec release in the alcohol, statin and alcohol+statin groups was increased compared with the control group and this increase was statistically significant only for the alcohol+statin group $(\mathrm{p}<0.001)$. In the alcohol+statin group it was significantly increased compared with the statin group $(\mathrm{p}$ $<0.001)$. The release cytochrome c levels of the statin+betaine group were found to be lower compared with alcohol and alcohol+statin group (respectively $\mathrm{p}<0.047, \mathrm{p}<0.010$ ). The release cytochrome c levels in the alcohol+statin+betaine group exhibited a significant reduction compared with the statin and alcohol+statin group (respectively $\mathrm{p}<0.010, \mathrm{p}<0.001)($ Tab. 1).

TNF- $\alpha$ Levels: TNF- $\alpha$ levels in the alcohol, statin and alcohol+statin groups were significantly increased compared 

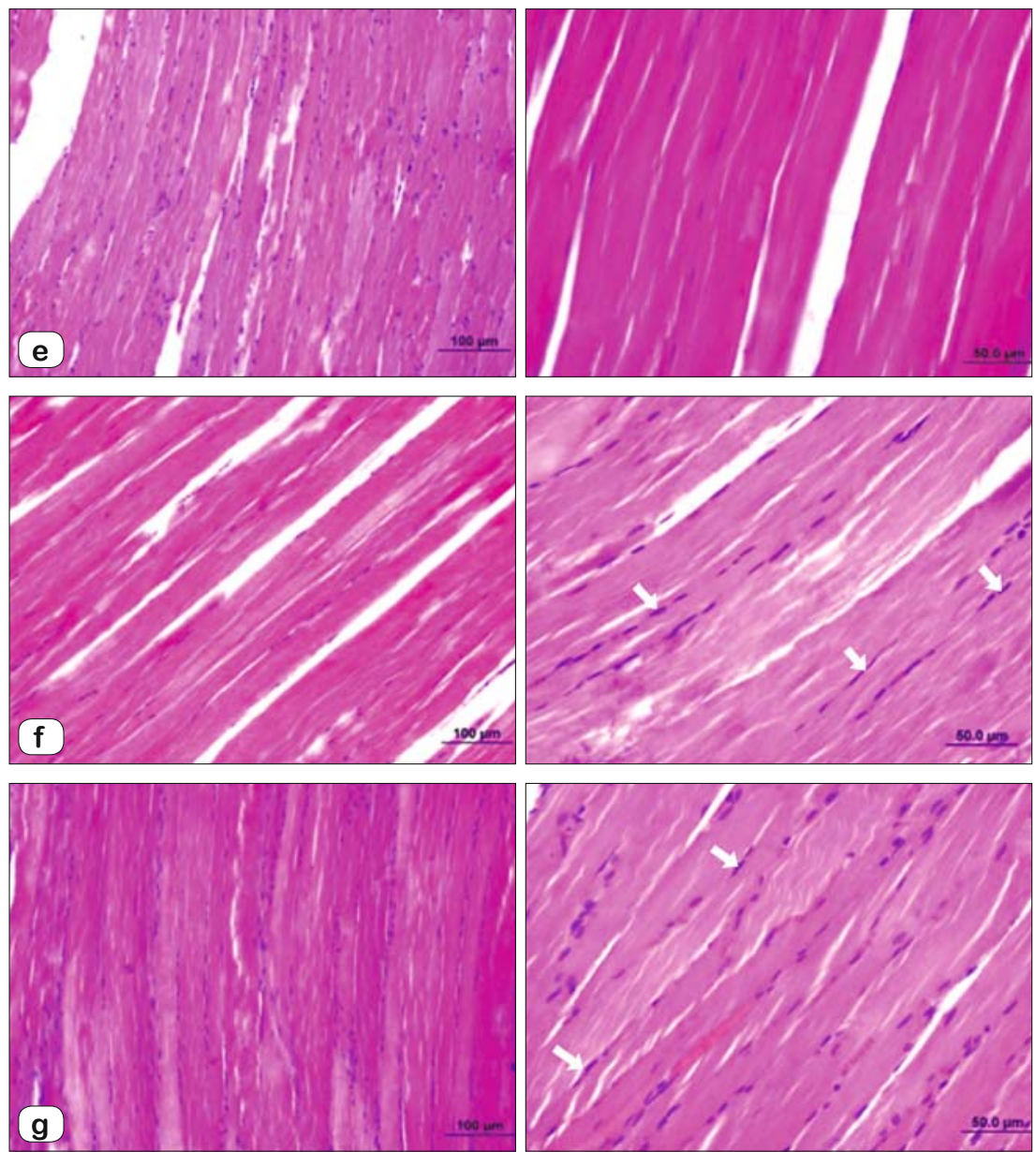

Fig. 2. Light microscope results in rat groups (a-g). e) Alcohol+betaine group: $(\rightarrow)$ Located peripheral nuclei (HE, scale bar: $100 \mu \mathrm{m}$, X20, scale bar: $50.0 \mu \mathrm{m}$, X40). f) Statin+betaine group: $(\rightarrow$ ) Located peripheral nuclei (HE, scale bar: $100 \mu \mathrm{m}$, X20, scale bar: $50.0 \mu \mathrm{m}$, X40). g) Alcohol+statin+betaine group: $(\rightarrow)$ Located peripheral nuclei (HE, scale bar: $100 \mu \mathrm{m}, \mathrm{X20}$, scale bar: $50.0 \mu \mathrm{m}, \mathrm{X} 40$ ).

with the control group $(\mathrm{p}<0.001)$. The TNF- $\alpha$ levels of the alcohol+betaine group were found to be lower compared with alcohol, statin and alcohol+statin group (respectively $\mathrm{p}<0.001$, $\mathrm{p}<0.010, \mathrm{p}<0.047)$. In the statin+betaine group the levels were decreased compared with the alcohol group $(\mathrm{p}<0.047)$. The TNF$\alpha$ levels in the alcohol+statin+betaine group exhibited a significant reduction compared with the alcohol, statin and alcohol + statin group (respectively $\mathrm{p}<0.010, \mathrm{p}<0.047, \mathrm{p}<0.048$ ) (Tab. 1).

NF-kB Levels: Compared with the control group, NF kB levels in the alcohol and alcohol+statin group were found to be statistically significantly higher (respectively $p<0.001, p<0.010$ ). In the alcohol+betaine, statin+betaine, alcohol+statin+betaine groups the levels were found to be decreased compared with the alcohol group and this decreased was statistically significant $(\mathrm{p}<0.010)$. The NF $\mathrm{kB}$ levels in the alcohol+statin group exhibited a significant increment compared with the alcohol+betaine group $(\mathrm{p}<0.047)$ (Tab. 1).

Caspase 3 enzyme activity: When the caspase 3 activities of the groups were assessed significantly, it was seen that the caspase 3 activity of alcohol+statin group statistically showed a significant increase compared to the control group $(\mathrm{p}<0.001)$. Caspase 3 activities of alcohol+statin group were statistically significantly increased compared with the alcohol and statin groups $(\mathrm{p}<0.001)$. The caspase 3 enzyme activities of the alcohol+betaine and alcohol+statin+betaine groups were found to be statistically lower compared with alcohol+statin group ( $<<0.001)$ (Tab. 1).

Calpain activity: Compared with the control group, calpain activities in the alcohol, alcohol+statin, statin and alcohol+betaine group were found to be statistically significantly higher (respectively $\mathrm{p}<0.001, \mathrm{p}<0.001, \mathrm{p}<0.047$, $\mathrm{p}<0.047)$. In the statin, alcohol+betaine and alcohol+statin+betaine groups the levels were found to be statistically decreased compared with the alcohol group $(p<0.047)$. The calpain activity of the statin+betaine group was found to be statistically lower compared with alcohol group $(\mathrm{p}<0.001)($ Tab. 1).

\section{Histological results}

Light microscope evaluation: Light microscopy results are shown in Figure 1. In light microscope evaluation, samples were scored according to the presence of necrosis, myofibrillar degeneration, nuclear proliferation, nuclear hypertrophy and edema. Obtained data was compared statistically. According to the data, necrosis rate was quite high in alcohol, statin and alcohol+statin groups compared to control group and this increase was significant $(\mathrm{p}<0.001)$. Necrosis rate was moderately high in statin+betaine and alcohol+betaine group compared to control group ( $\mathrm{p}<0.046)$. Necrosis in the alcohol + statin group was significantly increased compared to alcohol and statin groups. Necrosis rate was quite significantly decreased in alcohol+statin+betain group compared to alcohol and statin groups. Necrosis in the statin+betaine group was significantly reduced compared to statin groups $(\mathrm{p}<0.046)$. Necrosis rate was quite high in alcohol+statin group compared to statin+betaine and alcohol+betaine group and this increase was significant $(\mathrm{p}<$ 0.001) (Tab. 2).

Myofibrillar degeneration in the alcohol, statin and alcohol+statin groups were increased quite significantly compared to control group $(\mathrm{p}<0.001)$. Myofibrillar degeneration in the alcohol+statin group was increased quite significantly $(\mathrm{p}<0.001)$, alcohol+betaine and alcohol+statin+betaine groups were quite significantly decreased compared with alcohol group $(\mathrm{p}<0.001)$. Myofibrillar degeneration in the alcohol+statin group was quite 

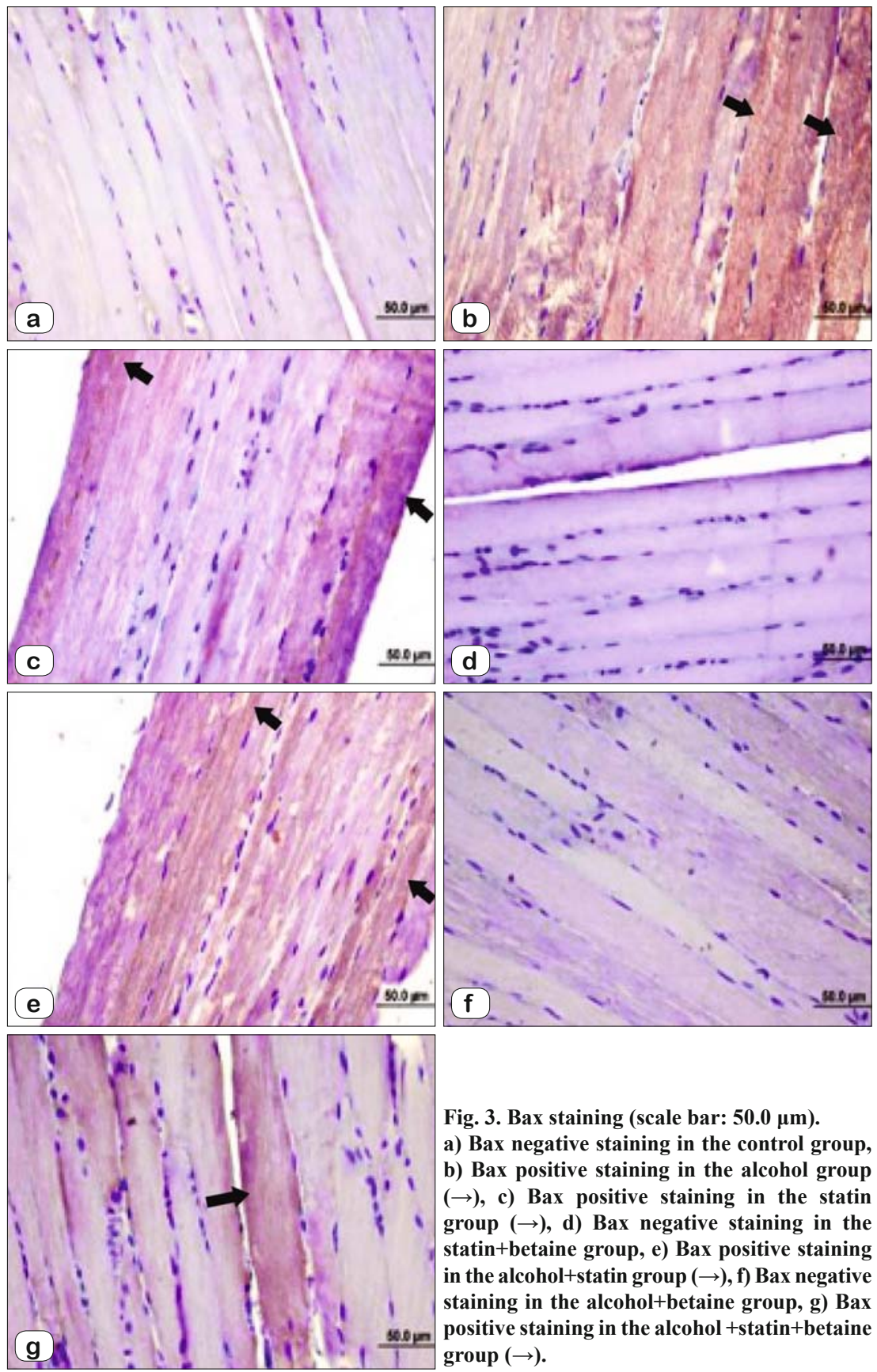

Fig. 3. Bax staining (scale bar: $50.0 \mu \mathrm{m}$ ).

a) Bax negative staining in the control group, b) Bax positive staining in the alcohol group $(\rightarrow)$, c) Bax positive staining in the statin group $(\rightarrow)$, d) Bax negative staining in the statin+betaine group, e) Bax positive staining in the alcohol+statin group $(\rightarrow)$, f) Bax negative staining in the alcohol+betaine group, g) Bax positive staining in the alcohol +statin+betaine group $(\rightarrow)$. was seen in statin+betaine, alcohol+betaine and alcohol+statin+betaine groups (respectively $\mathrm{p}<0.05, \mathrm{p}<0.05, \mathrm{p}<0.001)$. There was a significant increase in the statin group compared to the alcohol + statin group $(\mathrm{p}<0.001)$. This increase in proliferation was decreased significantly in the alcohol+statin+ betaine group $(\mathrm{p}<0.001)$. A significant decrease was observed in the alcohol+statin+ betaine group compared to the statin+betaine group ( $p<0.001)$. Compared with alcohol+statin group, a significant decrease was found in alcohol+betaine and alcohol+statin+betaine groups $(\mathrm{p}<$ 0.001) (Tab. 2).

Hypertrophy in alcohol, statin, statin+betaine, alcohol+statin and alcohol + betaine groups was increased quite significantly compared to control group (respectively $\mathrm{p}<0.001, \mathrm{p}<0.001, \mathrm{p}<0.046$, $\mathrm{p}<0.001, \mathrm{p}<0.001)$. A significant decrease was found in the alcohol+statin+betaine group $(\mathrm{p}<0.001)$, whereas a significant increase was observed in the alcohol+statin group compared to alcohol and statin groups $(\mathrm{p}<0.001)$. Hypertrophy in the alcohol + statin group was significantly higher than in the alcohol + betaine group $(\mathrm{p}<$ 0.001 ). Compared to alcohol + statin group, hypertrophy in the alcohol+statin+betaine groups was decreased statistically significantly ( $<<0.046)$ (Tab. 2).

Edema in connective tissue surrounding myofibrils of statin, alcohol and alcohol + statin groups was quite statistically higher than in the control group $(\mathrm{p}<$ 0.001). Statin + betaine and alcohol + betaine groups showed a significant increase in edema compared to the control group $(\mathrm{p}$ $<0.010$ ) (Tab. 2).

Edema in alcohol + statin group was statistically significantly higher than in the alcohol and statin groups $(\mathrm{p}<0.001)$, but significantly increased $(\mathrm{p}<0.001)$, whereas in the alcohol+betaine and alcohol+statin+betaine significantly decreased compared to statin group (respectively $\mathrm{p}<0.010$ and $\mathrm{p}<0.001$ ). Myofibrillar degeneration in the alcohol+statin+betaine group was decreased quite significantly compared to alcohol+statin group $(\mathrm{p}<0.001)$ (Tab. 2$)$.

Nuclear proliferation in myofibrills in the alcohol, statin, alcohol+statin and statin+betaine groups were increased quite significantly compared to control group $(\mathrm{p}<0.001)$. Compared with alcohol group, nuclear proliferation was increased statistically significantly in alcohol+statin group $(\mathrm{p}<0.001)$. A significant decrease
Tab. 3. Bax levels.

\begin{tabular}{ll}
\hline & \multicolumn{1}{c}{ Bax } \\
\hline Control & $0.20(0.00-1.00)$ \\
Alcohol & $1.30(1.00-2.00)^{\mathrm{a}}$ \\
Statin & $1.30(1.00-2.00)^{\mathrm{a}}$ \\
Alcohol+Statin & $2.90(2.00-3.00)^{\text {a.c.d }}$ \\
Alcohol+Betaine & $0.10(0.00-1.00)^{\mathrm{c}}$ \\
Statin+Betaine & $0.80(0.00-1.00)^{\mathrm{b}}$ \\
Alcohol+Statin+Betaine & $0.80\left(0.00-1.00^{\text {b.e }}\right.$ \\
\hline
\end{tabular}

a: Compared with control group $\mathrm{p}<0.05$, b: Compared with control group $\mathrm{p}<0.05$, $\mathrm{c}$ : Compared with alcohol group $\mathrm{p}<0.05$, d: Compared with statin+betaine group $\mathrm{p}$ $<0.05$, e:Compared with alcohol+statin group $\mathrm{p}<0.05$ 

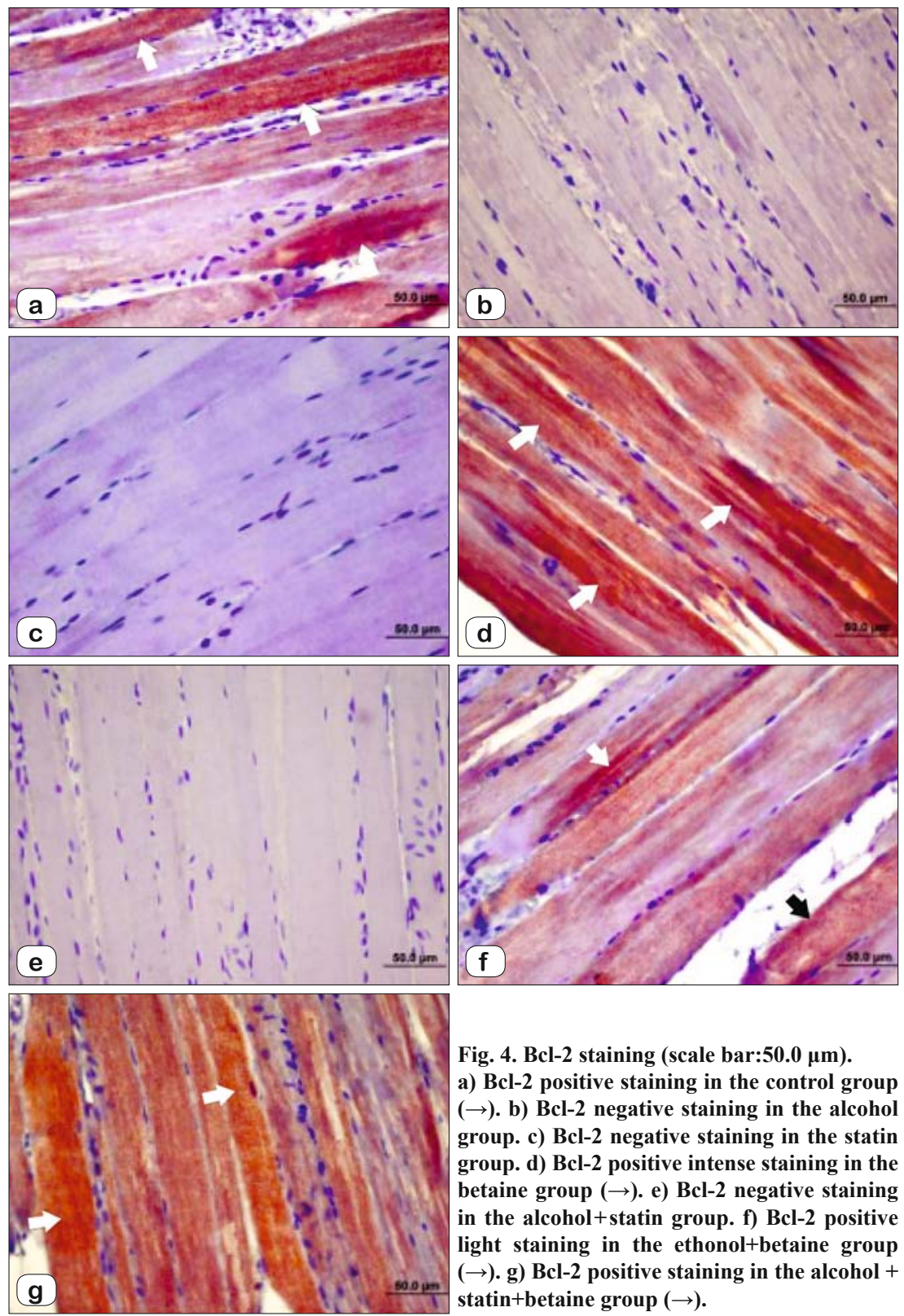

Fig. 4. Bcl-2 staining (scale bar:50.0 $\mu \mathrm{m}$ ). a) Bcl-2 positive staining in the control group $(\rightarrow)$. b) Bcl-2 negative staining in the alcohol group. c) Bcl-2 negative staining in the statin group. d) Bcl-2 positive intense staining in the betaine group $(\rightarrow)$. e) Bcl-2 negative staining in the alcohol+statin group. f) Bcl-2 positive light staining in the ethonol+betaine group $(\rightarrow)$.g) Bcl-2 positive staining in the alcohol + statin+betaine group $(\rightarrow)$. this increase was significantly reduced in the alcohol+statin + betaine group $(\mathrm{p}<0.001)$. The edema in the alcohol+statin group was significantly higher than in the alcohol +betaine and alcohol+statin+betain groups $(\mathrm{p}<0.001)$ (Tab. 2).

Bax Levels: When bax levels were examined in skeletal muscle specimens constituting all groups, there was a progressive increase in alcohol, statin, alcohol+statin groups ( $p<0.001)$, a statistically significant increase in statin+betaine and alcohol+statin+betaine groups $(\mathrm{p}<0.046)$. There was a significant increase in alcohol + statin group compared to alcohol group $(\mathrm{p}<0.001)$, this increase was significantly reduced in the alcohol+betaine group $(p<0.001)$. Bax levels in alcohol + statin group were higher than in the statin+ betaine group $(p<0.001)$. Statistically significant reduction in the alcohol+statin+betaine group was observed when compared with the alcohol + statin group ( $\mathrm{p}<0.001)$ (Tab. 3, Fig. 2).

Bcl-2 Levels: Bcl-2 levels were examined in skeletal muscle samples constituting all groups and it was found low in alcohol and statin groups and high in alcohol+ statin+betaine group when compared with control group $(\mathrm{p}<0.001)$. Bcl levels were high whereas it was low in alcohol+betaine group compared to alcohol group $(\mathrm{p}<0.001)$. Bcl-2 levels in alcohol + statin and statin + betaine groups were lower than in the statin group $(\mathrm{p}<$ 0.047 ). A significant increase was seen in the alcohol+statin + betain group compared with the statin group $(\mathrm{p}<0.001)$ (Tab. 4 , Fig. 3).

TUNEL results: Skeletal muscle samples were stained with TUNEL method and brown stained samples were evaluated as TUNEL $(+)$. TUNEL values were increased in skeletal muscle myopathy caused by alcohol, statin and combine using of alcohol+statin. Also this increased TUNEL values were decreased in the alcohol+statin+betaine group (Fig. 4).

\section{Discussion}

Excessive alcohol consumption and alcohol-related problems are also a major public health problem and result in large proportions of mortality and morbidity. Many factors influence the development of alcohol-related problems $(26,27)$. One of the most common causes of myopathy is the use of drugs from the statin group (7). The most commonly used antihyperlipidemic drugs are statins, HMG CoA reductase inhibitors, due to theit high activity and low side effect profile (28). Tiredness, weakness symptoms and myopathy are the most common side effect of statin drugs (7). It is estimated that at least 1.5 million

Tab. 4. Bcl-2 levels.

\begin{tabular}{ll}
\hline & \multicolumn{1}{c}{ Bcl-2 } \\
\hline Control & $1.40(1.00-2.00)$ \\
Alcohol & $0.20(0.00-1.00)^{\mathrm{a}}$ \\
Statin & $0.10(0.00-1.00)^{\mathrm{a}}$ \\
Alcohol+Statin & $0.80(0.00-1.00)^{\mathrm{c}}$ \\
Alcohol+Betaine & $1.00(0.00-2.00)^{\mathrm{b}}$ \\
Statin+Betaine & $0.80(0.00-1.00)^{\mathrm{c}}$ \\
Alcohol+Statin+Betaine & $2.70(2.00-3.00)^{\mathrm{a}, \mathrm{b}, \mathrm{c}, \mathrm{d}}$ \\
\hline
\end{tabular}

a: Compared with control group $\mathrm{p}<0.05, \mathrm{~b}$ : Compared with alcohol group $\mathrm{p}<0.05$, c: Compared with statin group $\mathrm{p}<0.05$, d: Compared with alcohol+statin+betaine group $\mathrm{p}<0.05$ 

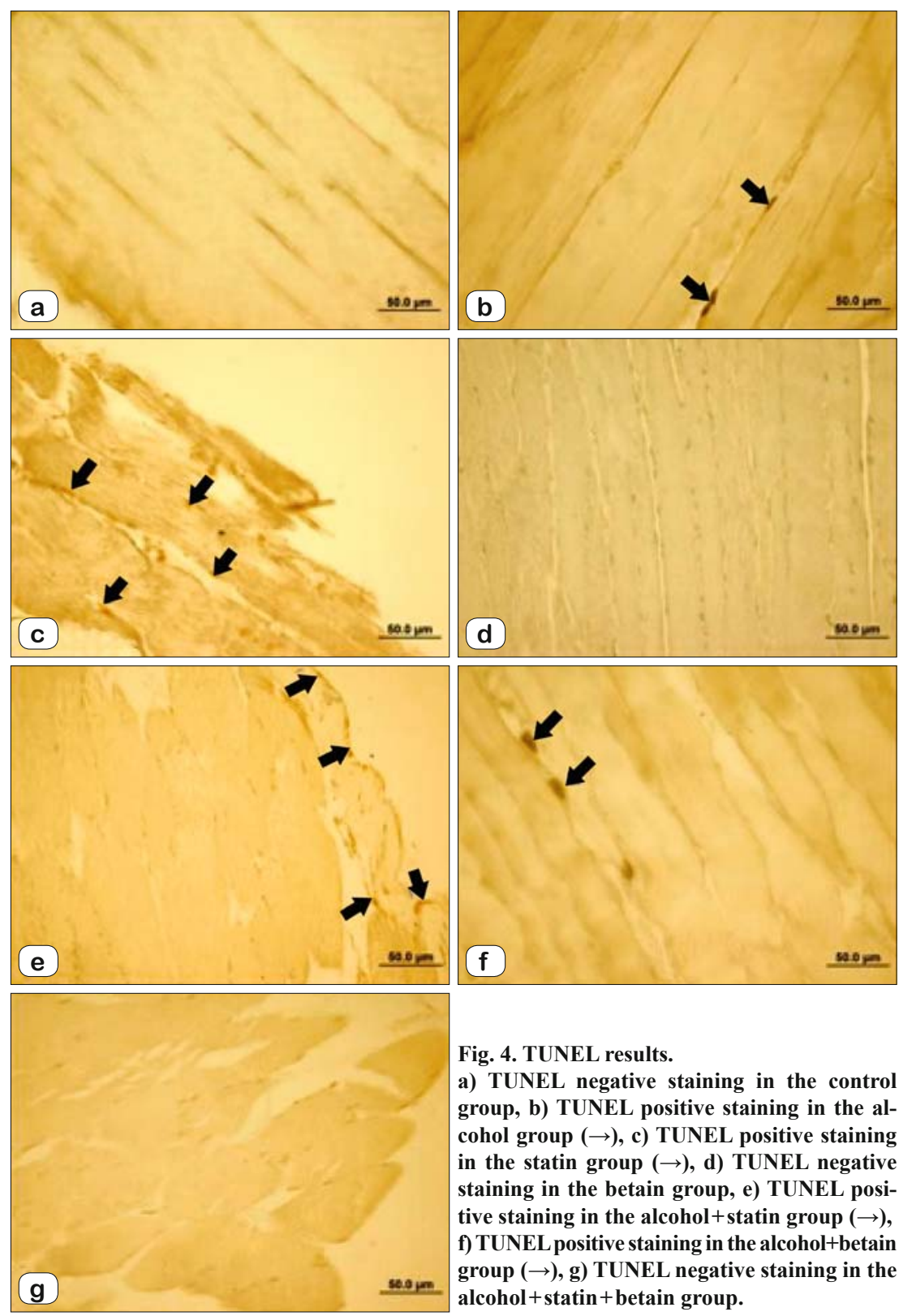

(d)
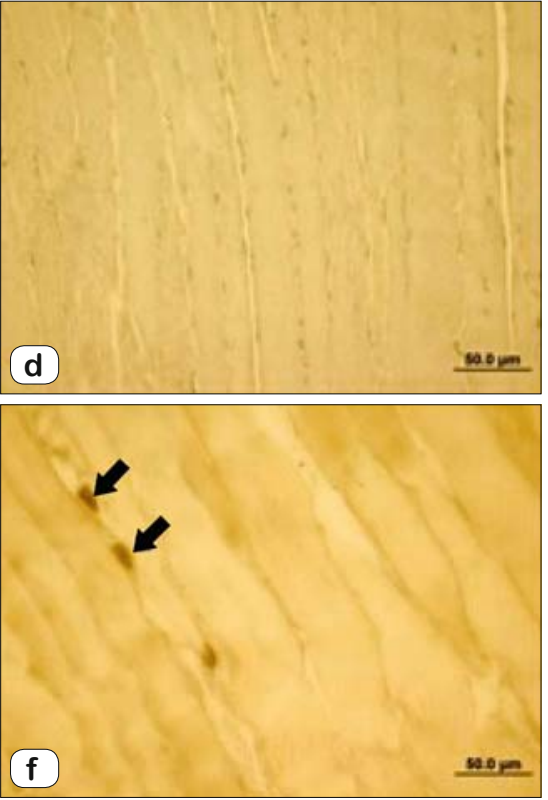

Fig. 4. TUNEL results.

a) TUNEL negative staining in the control group, b) TUNEL positive staining in the alcohol group $(\rightarrow)$, c) TUNEL positive staining in the statin group $(\rightarrow)$, d) TUNEL negative staining in the betain group, e) TUNEL positive staining in the alcohol+statin group $(\rightarrow)$, f) TUNEL positive staining in the alcohol+betain group $(\rightarrow)$, g) TUNEL negative staining in the alcohol+statin+ betain group.

an increased risk for the formation of myopathy (31). Paralleling this study, increase in creatine kinase levels was observed in combining of alcohol and statin group.

It is known that long term alcohol use has an apoptosis-initiation effect by impairing mitochondrial permeability. In this way, cytochrome $\mathrm{c}$ is released into the cytosol and binds with Apaf-1 and activated caspase-9. The proteolytic activity of caspase- 9 activates caspase- 3 and apoptosis is initiated (34). In our study to determine the effect of statin and alcohol use on muscle, we measured the release of mitochondrial cytochrome c into the cytosol. We also measured the amount of cytochrome c remaining in the mitochondria and estimated cytosol to mitochondria ratio. Because of this ratio, as the cytochrome $\mathrm{c}$ content decreases in the mitochondrial fraction when the cytosol penetration increases, the ratio between them also increases remarkably. As in earlier studies, this rate represents mitochondrial damage (35). In our study this ratio increased in alcohol, statin, and alcohol + statin groups, but the highest increase was seen in alcohol + statin group. These results have also affected the results of caspase-3, since cytosol-releasing cytochrome $\mathrm{c}$ is involved in the caspase- 9 activation necessary for the activation of caspase-3 (36). In parallel with our cytochrome c results, the highest increase was in our alcohol + statin group. We attributed the highest cytrochrome $\mathrm{c}$ and caspase 3 results in the alcohol + statin group to the effect of apoptosis both using alcohol and statin separately. Human and rodent studies have shown that statin administration induced apoptosis in the skeleton $(37,38,39)$.

The use of statin causes an increase in cytosolic calcium resulting in a change in

people have muscle complaints related to statin use annually (29). An increase in creatine kinase levels biochemically is observed in statin-bound myotoxicity (30). In our study, creatinine kinase levels were increased in alcohol and statin treated groups. Pasternak and colleagues concluded that the combined use of ethanol and statin in the study was an increasing risk factor for myopathy (31). In parallel with this study, in our study the greatest increase in creatine kinase levels was also noted in the group in which alcohol and statin were given together. However, Studies have also shown normal creatine kinase levels in statin-dependent myotoxicity $(32,33)$. In our study creatine kinase levels were increased in the alcohol and statin given groups. In previous study, Pasternak and colleagues have argued that the combined use of ethanol and statin represents synthesis of isoprenoid. Increased levels of calcium also cause activation of the calpains. Calpains generate apoptosis by initiating caspase cascade (7). In our study, there was a statistically significant increase in the statin group compared to the control group. Rajgopal et al. demonstrated that calpains are active in cell death caused by ethanol (40). In our study, calpain levels of alcohol and alcohol + statin group had a significant increase compared to control group.

Studies have shown that there is a decrease in the ratio of $\mathrm{Bcl} 2 /$ Bax that causes cytochrome $\mathrm{c}$ release in statin-induced apoptosis in skeletal muscle (7). Our results of our Bcl-2/Bax in our histology findings support this decrease. In another study; an increase in TUNEL values was observed in skeletal muscle myopathy caused by alcohol (41). 
Histological examinations of our study showed that, necrotic myofibrils and intense nuclear proliferation are evident in alcohol and statin groups, while partial edema, vacuolization, centrally located nuclei, nuclear proliferation in the myofibrils and necrotic myofibrils in the alcohol+statin group in association with these were shown previous studies. Alcohol +betaine+statin group showed decreased myofibril damage and muscular cells in histological structure near normal cells.

Betaine is lipotropic and passes through the lipid layer quickly when given externally and inhibits lipid peroxidation in cellular membranes. The addition of betaine to protect against necrotic damage is shown in a study by Kim et al (42). As in our previous study with betaine (43), in this study, betaine-treated treatment groups showed that calpain and caspase activities and cytokine c release were decreased caused by alcohol, statin and more importantly alcohol + statin, and TNF and NF kB levels were also close to the control group.

Similarly, significant improvements have been observed in our morphological and histological examination results that are also supported by our biochemical data.

In conclusion, our findings in this experimental study suggested that alcohol and statin combined consumption increase apoptotic cellular degeneration in the skeletal muscles and following betaine treatments can cause a decrease in this apoptotic damage. We have found protective efficacy of betaine and believe that these findings will be a stepping stone for future studies. Further studies are also needed about the possible effects of application of this supplement.

\section{References}

1. Yilmaz S. İlaca bağli miyopatiler. Uludağ Üniversitesi Tip Fakültesi Dergisi. 2010; 34 (3): 129-133.

2. Alkiş K. Hiperkolesterolemi oluşturulmuş farelerde kefirin ve statin içerikli ilaçlarin kolesterol üzerinde etkilerinin araştirilmasi. Kafkas Üniversitesi, Fen Bilimleri Enstitüsü, Biyoloji Anabilim Dali, Yüksek Lisans Tezi, Kars, 2009.

3. Öztürk GT. Atorvastatin kullanan hastalarda kas performasinin izokinetik test ile değerlendirilmesi. Gazi Üniversitesi Tip Fakültesi Fiziksel Tip Ve Rehabilitasyon Anabilim Dali, Uzmanlik Tezi, Ankara, 2010.

4. Solakoğlu Z. Apoptoz varliği ya da yokluğu bir hastalik nedeni. İstanbul Üniversitesi, İstanbul Tip Fakültesi, Fizyoloji Anabilim Dali, İstanbul, 2010.

5. Liu L, Sakai T, Sano N, Fukui K. Nucling mediates apoptosis by inhibiting expression of galectin-3 through interference with nuclear factor kB signaling. Biochemical Journal 2004; 380: 31-41.

6. Yanmaz MT. Kolorektal kanserde epidermal büyüme faktörü reseptörü ve nükleer factor kappa b ekspresyonunun prognoza etkisi. İstanbul Üniversitesi, Cerrahpaşa Tip Fakültesi, Tibbi Onkoloji Abd, Uzmanlik Tezi, 2006.

7. Dirks AJ, Jones KM. Statin-induced apoptosis and skeletal myopathy. American Journal of Physiology-Cell Physiology 2006; 291: 1208-1212.

8. Aslan A. Ratlarda azoksimetan uygulanarak oluşturulan kolorektal kanserde likopenin siklooksijenaz-2 (cox-2), kaspaz-3, kaspaz-9, bax, bcl-2, p53 proteinlerinin ekspresyonu ve DNA hasari üzerine etkisi. Firat Üniversitesi Fen Bilimleri Enstitüsü, Doktora Tezi, 2011.
9. Binen M. Kalpain inhibitörü olan AK295"e in siçanlarda renal iskemireperfüzyon hasarinda kaspaz 3'e olan etkisinin araştirilmasi. İnönü Üniversitesi Fen Bilimleri Enstitüsü, Yüksek Lisans Tezi Biyoloji Anabilim Dali Malatya, 2011.

10. Kar P, Samanta K, Shaikh S, Chowdhury A, Chakraborti T, Chakraborti S. Mitochondrial calpain system: An overview. Archives Of Biochemistry And Biophysics 2010; 495:1-7.

11. Kuralay F, Çavdar Z. İnflamatuar medyatörlere toplu bir bakiş. Genel Tip Dergisi 2006; 16, 3, 143-152..

12. Fernández-Solà J, Nicolás JM, Fatjó F, García G, Sacanella E, Estruch R et al. Evidence of apoptosis in chronic alcoholic skeletal myopathy. Human Pathology 2003; 34, 12.

13. Fernandez-Solà J, Preedy VR, Lang CH, Gonzalez-Reimers E, Arno M, Lin JC. Molecular and cellular events in alcohol-induced muscle disease. Alcoholism: Clinical and Experimental Research 2007; 31, 12.

14. Gill C, Mestril R, Smali A. Losing heart: the role of apoptosis in heart disease--a novel therapeutic target?. The FASEB Journal 2002; 16 (2): $135-46$.

15. Cai J, Yang J, Jones DP. Mitochondrial control of apoptosis: the role of cytochrome c. Biochimica et Biophysica Acta 1998;1366:139-149.

16. Craig SA. Betaine in human nutrition. The American Journal of Clinical Nutrition 2004; 80: 539-549.

17. Welch WC, Brown CR. Influence of molecular and chemical chaperones on protein folding. Cell Stress Chaperones 1996; 1: 109-115.

18. Ratter F, Germer M, Fischbach T, Schulze-Osthoff K, Peter ME, Dröge W et al. S-Adenosylhomocysteine as a physiological modulator of apo-1-mediated apoptosis. International Immunology 1996; $8: 1139-47$.

19. Galan AI, Munoz ME, Jimenez R. S-Adenosylmethionine protects against cyclosporin a-induced alterations in rat liver plasma membrane fluidity and functions. Journal of Pharmacology and Experimental Therapeutics 1999; 290: 774-781.

20. Baysan O, Kaptan K, Erinç K, Oztas Y, Coskun T, Kayir H et al. Chronic heavy alcohol consumption is associated with decreased platelet aggregation in rats. The Tohoku Journal of Experimental Medicine 2005; 206: 85-90.

21. Erinç K, Barçin C, Ozsoy N,Oztaş E, Gül N, Sağ C et al. Effects of chronic alcohol consumption on myocardial ischemia in rats. Pharmacological Research 2003; 47:175-180.

22. Zovein A, Flowers-Ziegler J, Thamotharan S, Shin D, Sankar R, Nguyen $\mathbf{K}$ et al. Postnatal hypoxic-ischemic brain injury alters mechanisms mediating neuronal glucose transport. American journal of physiology,Regulatory, integrative and comparative physiology 2004; 286 (2): $273-282$.

23. Soeda J, Miyagawa S, Sano K, Masumoto J, Taniguchi S, Kawasaki S. Cytochrome c release into cytosol with subsequent caspase activation during warm ischemia in rat live. American Journal of Physiology-Gastrointestinal and Liver Physiology 2001; 281 (4): 1115-1123.

24. Grunnet LG, Aikin R, Tonnesen MF,Paraskevas S, Blaabjerg L, Størling J et al. Proinflammatory cytokines activate the intrinsic apoptotic pathway in beta-cells. Diabetes 2009; 58,8 .

25. McDonald MC, Mota-Filipe H, Paul A, Cuzzocrea S, Abdelrahman M, Harwood S et al. Calpain inhibitor I reduces the activation of nuclear factor-kb and organ injury/dysfunction in hemorrhagic shock. The FASEB Journal 2001; 15 (1): 171-186. 
26. Nguyen VA, Le T, Tong M, Silbermann E, Gundogan F, M. de la Monte $\mathbf{S}$ et al. Impaired insulin/igf signaling in experimental alcoholrelated myopathy. Nutrients 2012; 4, 1058-1075.

27. Akvardar Y, Uçku R. Alkol kullanim sorunlari nasil önlenir? Alkol kullanim bozukluklarinin tani ve tedavisinde kisa müdahale yaklaşimi. Anadolu Psikiyatri Dergisi 2010;11 (1): 51-59.

28. Etli M. Hemodiyaliz amaçli açilan arterio-venöz fistüllerde gelişen endotel disfonksiyonuna statinlerin etkisi. Süleyman Demirel Üniversitesi Tip Fakültesi, Uzmanlik Tezi Kalp Ve Damar Cerrahisi Anabilim Dali, Isparta, 2011.

29. Taşoğlu, Ö. Miyaljide D vitamini ve statin ilişkisi: Statin kullanan hastalarda D vitamini eksikliği miyalji gelişimi içi bir risk faktörü müdür?. Hacettepe Üniversitesi Tip Fakültesi Fiziksel Tip Ve Rehabilitasyo Anabilim Dali, Ankara, 2012.

30. Tomaszewski M, Stepien MK, Tomaszewska J, Czuczwar SJ. Statininduced myopathies. Pharmacological Reports 2011; 63 (4): 859-66.

31. Pasternak RC, SmithJr SC, C. Noel Bairey-Merz, Grundy SM, Cleeman JI, Lenfant C. ACC/AHA/NHLBI clinical advisory on the use and safety of statins. Circulation 2002; 106, 1024-1028.

32. Bennett WE, Drake AJ, Shakir KM. Reversible myopathy after statin therapy in patients with normal creatine kinase levels. Annals of Internal Medicine 2003; 138, 436-437.

33. Phillips PS, Haas RH, Bannykh S. Statin associated myopathy with normal creatine kinase levels. Annals of Internal Medicine 2002; 137, $581-585$.

34. Higuchi H, Adachi M, Miura S, Gores GJ, Ishii H. The mitochondrial permeability transition contributes to acute ethanol-induced apoptosis in rat hepatocytes. Hepatology 2001; 34(2): 320-328.
35. Burgess DH, Svensson M, Dandrea T, Grönlund K, Hammarquist F, Orrenius S et al. Human Skeletal muscle cytosols are refractory to cytochrome $\mathrm{c}$ dependent activation of type-II caspases and lack apaf-1. Cell Death Differ 1999; 6, 256-261.

36. Gill C, Mestril R, Samali A. Losing heart: The role of apoptosis in heart disease - a novel therapeutic target. The FASEB Journal 2002; 16.

37. Kobayashi M, Kaido F, Kagawa T, Itagaki S, Hirano T, Iseki K Preventive effects of bicarbonate on cerivastatin-induced apoptosis. International Journal of Pharmaceutics 2007; 341, 181-188.

38. Kaufmann P, Török M, Zahno A, Waldhauser KM, Brecht K, Krähenbühl S. Toxicity of statins on rat skeletal muscle mitochondria. Cellular and Molecular Life Sciences 2006; 63, 2415-2425.

39. Demyanets S, Kaun C, Pfaffenberger S, Hohensinner PJ, Rega G, Pamme $\mathbf{J}$ et al. Hydroxymethylglutaryl-coenzyme A reductase inhibitors induce apoptosis in human cardiac myocytes in vitro. Biochemical Pharmacology 2002; 71, 1324-1330.

40. Rajgopal Y, Vemuri MC. Calpain activation and a-spectrin cleavage in rat brain byethanol. Neuroscience Letters 2002; 321, 187-191.

41. Fernández-Solà J, Nicolás JM, Fatjó F, García G, Sacanella E, Estruch R et al. Evidence of apoptosis in chronic alcoholic skeletal myopathy. Human Pathology 2003; 34 (12): 1247-1252.

42. Kim SK, Kim YC. Effects of singly administered betaine on hepatotoxicity of chloroform in mice. Food and Chemical Toxicology 1998; $36,655-661$.

43. OI KK, Kanbak G, Ilhan AO, Burukoglu D, Yücel F. The investigation of the prenatal and postnatal alcohol exposure-induced neurodegeneration in rat brain: protection by betaine and/or omega-3. Childs Nerv Syst 2016; 32:467-474. 